\title{
Penggunaan Minyak Ikan dalam Ransum Ayam Kampung terhadap Profil Lemak Darah
}

\author{
Anhar Faisal Fanani ${ }^{1 *}$, Nurul Fajrih ${ }^{1}$ dan Wa Laili Salido ${ }^{2}$ \\ ${ }^{1}$ FakultasSains dan Teknologi, Universitas Nahdlatul Ulama Lampung \\ Jl. Hanafiah Lintas Timur, Mataram Marga, Kec. Sukadana, Lampung Timur. 34194 \\ ${ }^{2}$ Fakultas Peternakan, Universitas Halu Oleo \\ Jl. H.E.A. Mokodompit Kampus Hijau Bumi Tridharma, Kambu, Kendari. 93232 \\ *Email korespondensi: anharfaisalf@yahoo.com
}

(Diterima: 4-11-2018; disetujui 25-11-2018)

\begin{abstract}
ABSTRAK
Tujuan penelitian adalah mengevaluasi level penambahan minyak ikan lemuru dalam ransum ayam kampung terhadap profil lemak darah.Materi penelitian yang digunakan adalahayam kampung betina umur 24 minggu. Bahan pakan yang digunakan adalah minyak ikan lemuru, bekatul, jagung giling, bungkil kedelai, minyak sawit, tepung ikan, dan premix multi mineral dan vitamin. Metode penelitian menggunakan rancangan acak lengkap (RAL). Perlakuan yang diberikan adalah $\mathrm{T}_{0}=$ Penggunaan minyak ikan lemuru sebanyak $0 \%, \mathrm{~T}_{1}=$ Penggunaan minyak ikan lemuru sebanyak $2 \%, \mathrm{~T}_{2}=$ Penggunaan minyak ikan lemuru sebanyak $4 \%, \mathrm{~T}_{3}=$ Penggunaan minyak ikan lemuru sebanyak $6 \%$. Parameter yang diamati adalah kolesterol total, kadar High Density Lipoprotein (HDL) dan Low Density Lipoprotein (LDL) darah ayam kampung. Data dianalisis menggunakan analisis variansi yang dilanjutkan uji duncan.Hasil penelitian menunjukkan bahwa perlakuan dengan minyak ikan lemuru pada level tertinggi berpengaruhnyata $(\mathrm{P}<0,05)$ terhadap kolesterol total, kadar HDL dan LDL darah.Kesimpulan penelitian adalah pemberian minyak ikan lemuru sampai $6 \%$ dapat digunakan dalam campuran pakan ayam kampung.
\end{abstract}

Kata kunci: Profil lemak darah, ayam lokal, minyak ikan lemuru

\section{ABSTRACT}

The aimed of the study was to evaluate the level of addition lemuru fish oil in the ration of local chicken on the blood fat profile. The research materials used was female local chickens aged 24 weeks. The feed materials used are lemuru fish oil, rice bran, milled corn, soybean meal, palm oil, fish meal as well as multimineral and vitamin premix. The research method using a complete by randomized design. The treatments are given wereT $0=$ lemuru fish oil as much as $0 \%, \mathrm{~T} 1=$ lemuru fish oil as much as $2 \%$, $\mathrm{T} 2=$ lemuru fish oil as much as $4 \%, \mathrm{~T} 3=$ lemuru fish oil as much as $6 \%$. The observed variables were total cholesterol, levels of high-density lipoprotein (HDL) and low-density lipoprotein (LDL) of local chicken blood. The data were analyzed using analysis of variance and was continued with Duncan test. The results showed that the treatment with lemuru fish oil at the highest level had a significant effect $(\mathrm{P}<0.05)$ on total cholesterol, HDL levels, and LDL blood. The conclusion of the study is that the provision of lemuru fish oil up to $6 \%$ can be used in native chicken feed mix.

Keywords: The blood fat profile, local chicken, lemuru fish oil

\section{PENDAHULUAN}

Peningkatan produksi dan reproduksi unggas khususnya ayam lokal dipengaruhi oleh faktorgenetik dan manajemen. Faktor manajemen diantaranya adalah pakan yang diberikan. Peningkatkan produksi berupa telur dan daging telah diupayakan dengan pemberian pakan sesuai kebutuhan. Kekawatiran masyarakat terhadap produk unggas karena pada produk yang dihasilkan mengandung kolesterol yang tinggi. Sehingga, untuk meningkatkan kualitas dapat diupayakan dengan menghasilkan produk rendah kolesterol.

Kolesterol terdapat di dalam darah bersama dengan trigliserida, fosfolipid, dan apoprotein membentuk lipoprotein. Lipoprotein di darah, yaitu kilomikron, Very Low Density 
Lipoprotein (VLDL), Low Density Lipoprotein (LDL) dan High Density Lipoprotein (HDL) (Hartini \& Okid, 2009). Kadar kolesterol dapat dipengaruhi oleh pakan yang dikonsumsi ternak. Lemak yang tinggi dalam pakan akan mengakibatkan terjadinya kenaikan kadar LDL dalam darah yang merupakan lipoprotein yang kaya akan kolesterol (Nurul, 2016), sehingga perlu upaya untuk menghasilkan produk ternak yang rendah kolesterol yaitu dengan penggunaan minyak ikan lemuru.

Minyak ikan telah dilaporkan memiliki berbagai efek yang bermanfaat bagi kesehatan, antara lain anti karsinogenik, anti aterogenik,antidiabetes, dan efek stimulasi kekebalan tubuh (Mariod et al., 2015). Pakan dengan kandungan asam lemak tidak jenuh terdapat pada bahan pakan nabati dan minyak ikan yakni pada minyak ikan lemuru. Ikan lemuru merupakan ikan yang hidup di perairan selat bali, sementara minyak ikan lemuru merupakan limbah hasil pengelolaan ikan lemuru dari proses pengalengan dan proses pembuatan tepung ikan. Minyak ikan lemuru saat ini belum dimanfaatkan secara maksimal, tetapi berpotensi sebagai sumber asam lemak tidak jenuh, sehingga dapat digunakan sebagai bahan penyusun pakan ayam.

Pemberian asam lemak tak jenuh yang berasal dari minyak ikan lemuru dalam ransum ayam kampung merupakan upaya untuk meningkatkan kadar HDL dan menurunkan kadar Kolesterol total dan LDL darah. Minyak ikan lemuru yang telah mengalami ekstraksi mempunyai kandungan asam lemak tak jenuh ganda Omega-3 sebesar 34,9 \% (Amiluddin, 2014). Hal tersebut didukung oleh hasil penelitian Mariod et al., (2015) bahwa pemberian minyak ikan pada level 3\% ke dalam ransum ayam petelur, mampu meningkatkan berat telur dan persentase produksi telur dibandingkan perlakuan kontrol. Selanjutnya oleh penelitian Adebisi et al. (2017) menemukan bahwa penambahan minyak ikan sebesar $0,75 \%+$ minyak kacang kedelai $0,75 \%$ nyata menurunkan $(\mathrm{P}<0,05)$ LDL darah ayam petelur namun tidak terhadap kolesterol darah dan trigliserida. Oleh karena perlu dilakukan penelitian terkait profil lemak darah pada ayam lokal yang diberi minyak ikan lemuru.

\section{MATERI DAN METODE}

Materi yang digunakan dalam penelitian ini adalah ayam kampung betina umur 24 minggu dengan bobot badan berkisar 1,6-1,7 $\mathrm{kg}$. Ayam diletakkan secara acak pada kandang batre individu dengan ukuran $40 \times 30 \times 40 \mathrm{~cm}$. Pakan untuk perlakuan terdiri dari 4 perlakuan yang diulang sebanyak lima kali dan setiap ulangan terdiri dari 3 ekor sehingga totalkeseluruhan berjumlah 60 unit percobaan. Bahan pakan yang digunakan antara lain tepung ikan, minyak kelapa sawit, bungkil kedelai, bekatul, jagung giling, $\mathrm{CaCO} 3$, multi vitamin dan mineral mix serta bahan perlakuan yakni minyak ikan lemuru. Ransum penelitian disusun dengan iso protein dan energi seperti pada Tabel 1.

Tabel 1. Ransum percobaan dan kandungan nutrien

\begin{tabular}{lcccc}
\hline Susunan Ransum & To & $\mathbf{T}_{\mathbf{1}}$ & $\mathbf{T}_{\mathbf{2}}$ & $\mathbf{T}_{\mathbf{3}}$ \\
\hline Bahan Pakan & & & & \\
Jagung giling & 48,4 & 40 & 30 & 27 \\
Bekatul & 26 & 33 & 41,5 & 42 \\
Bungkil kedelai & 14 & 13,5 & 13 & 13,5 \\
Tepung ikan & 9 & 9 & 9 & 9 \\
Minyak ikan lemuru & 0 & 2 & 4 & 6 \\
Minyak kelapa sawit & 0,3 & 0,2 & 0,2 & 0,2 \\
CaCO3 & 2 & 2 & 2 & 2 \\
Premix multi vitamin dan mineral & 0,3 & 0,3 & 0,3 & 0,3 \\
\hline Total & $\mathbf{1 0 0 , 0 0}$ & $\mathbf{1 0 0 , 0 0}$ & $\mathbf{1 0 0 , 0 0}$ & $\mathbf{1 0 0 , 0 0}$ \\
\hline Kandungan Nutrien: & & & & 2896,50 \\
Energi metabolis (kkal/kg) & 2739,10 & 2740,50 & 2736,05 & 17,42 \\
Protein kasar(\%) & 17,05 & 16,95 & 17,10 & 6,29 \\
Serat kasar (\%) & 5,02 & 5,61 & 6,02 & 6,86 \\
Lemak kasar (\%) & 6,65 & 8,5 & 8,64 & 2,54 \\
Ca (\%) & 2,61 & 2,46 & 2,57 & 1,33 \\
P (\%) & 1,29 & 1,24 & 1,23 & \\
\hline
\end{tabular}


Pakan perlakuan dilakukan selama 6 minggu yang sebelumnya dilakukan pendahuluan selama 1 minggu dengan ransum tanpa minyak ikan lemuru, pada saat pendahuluan sebelumnya ayam diberi vaksin ND. Pemberian ransum dibatasi sebanyak 110gram/ekor/hari dan air minum diberikan secara tak terbatas. Pemberian ransum dilakukan 2 kali sehari yakni pada pukul 07.00 dan 16.00. Perlakuan yang diteliti adalah sebagai berikut:

$\mathrm{T}_{0}=$ Penggunaan minyak ikan lemuru $0 \%$

$\mathrm{T}_{1}=$ Penggunaan minyak ikan lemuru $2 \%$

$\mathrm{T}_{2}=$ Penggunaan minyak ikan lemuru 4\%

$\mathrm{T}_{3}=$ Penggunaan minyak ikan lemuru $6 \%$

Parameter yang diukur dalam penelitian ini adalah profil lemak darah yang meliputi kolesterol total, kadar High Density Lipoprotein (HDL) dan Low Density Lipoprotein (LDL) darah pada ayam kampung. Sampel darah diambil satu ekor ayam tiap ulangan, pengambilan darah dilakukan pada akhir penelitian. Darah diambil melalui vena pectoralis sebanyak $3 \mathrm{ml}$ dengan spuit syringe ukuran $5 \mathrm{ml}$. Syringe yang digunakan pada masing-masing sampel berbeda, selanjutnya sampel darah dimasukkan ke dalam tabung EDTA. Sampel darah yang diperoleh disentrifuge dengan kecepatan 3.500 rpm kurang lebih 10 menit. Supernatan berupa serum diambil dengan pipet steril dan ditempatkan pada tabung evendorf dan siap untuk dianalisis (Nurul, 2016). Data yang diperoleh selanjutnya dianalisis menggunakan analisis variansi yang dilanjutkan dengan uji duncan.

\section{HASIL}

Low density Lipoprotein (LDL) merupakan agen pengangkut yang mengandung 25\% protein, kolesterol sebesar $45 \%$ dan sisanya fospolipid serta trigliserida. Berdasarkan data pada Tabel 2 menunjukkan bahwa pemberian minyak ikan lemuru pada ransum ayam kampung berpengaruh nyata $(\mathrm{P}<0,05)$ terhadap kadar LDL serum darah, hal tersebut disebabkan karena Omega-3 mampu menghambat biosintesis lemak dihati. Menurut Marks et al. (2000) bahwa kadar LDL dapat dipengaruhi oleh asupan pakan yang dikonsumsi. Dijelaskan lebih lanjut bahwa peningkatan konsumsi pakan juga dapat mempengaruhi kadar lemak darah. Rataan konsumsi pakan yang tidak mengandung minyak ikan lemuru adalah 96,74 gram, sedangkan rataan konsumsi pakan yang mengandung minyak ikan lemuru $2 \%$ adalah 98,78 gram, $4 \%$ adalah 100,66 gram, dan konsumsi pakan yang mengandung minyak ikan lemuru $6 \%$ memiliki rataan tertinggi yaitu 101,13 gram. Dalam penelitian ini terjadi sedikit peningkatan konsumsi pakan pada perlakuan khususnya $\mathrm{T} 3$ dengan nilai konsumsi tertinggi namun dengan pemberian minyak ikan lemuru mampu menurunkan kadar LDL seperti yang diharapkan.

Penurunan tersebut dapat dihubungkan dengan pemberian minyak ikan lemuru terhadap kadar LDL darah. Hal ini sesuai dengan penelitian (Chashnidel et al., 2009) yang mendapat hasil kadar LDL darah semakin turun pada penambahan asam lemak tidak jenuh. Asam lemak tak jenuh ganda cenderung menurunkan kadar kolesterol darah dan mengurangi kelengketan keping-keping darah. Kadar kolesterol darah mempunyai hubungan erat dengan kadar LDL darah karena LDL mengandung kolesterol yang paling banyak yaitu $55 \%$.

Pengangkutan lemak diatur melaui 2 jalur, yaitu jalur eksogen dan endogen. Jalur eksogen yaitu penyerapan lemak dalam bentuk trigliserida dan kolesterol yang berasal dari pakan melalui usus disertai dengan pembentukan kilomikron serta beredar dalam darah. Jalur endogen terjadi sintesis partikel VLDL oleh hati yang mengandung apoprotein serta akan diedarkan melalui aliran darah.

Tabel 2. LDL (Low Density Lipoprotein), HDL (High Density Lipoprotein) dan Kolesterol Total Darah Ayam Kampung

\begin{tabular}{lcccc}
\hline \multirow{2}{*}{\multicolumn{1}{c}{ Parameter }} & \multicolumn{4}{c}{ Perlakuan } \\
\cline { 2 - 5 } & 40 & T1 & T2 & T3 \\
\hline LDL (mg/dl) & $42,57 \pm 14^{\mathrm{a}}$ & $27,63 \pm 12^{\mathrm{b}}$ & $30,55 \pm 4^{\mathrm{ab}}$ & $24,36 \pm 11^{\mathrm{b}}$ \\
HDL (mg/dl) & $41,22 \pm 10^{\mathrm{ab}}$ & $40,36 \pm 9^{\mathrm{b}}$ & $44,24 \pm 19^{\mathrm{ab}}$ & $49,64 \pm 14^{\mathrm{a}}$ \\
Kolesterol Total (mg/dl) & $140,77 \pm 15^{\mathrm{a}}$ & $141,79 \pm 18^{\mathrm{ab}}$ & $135,47 \pm 8^{\mathrm{b}}$ & $115,22 \pm 11^{\mathrm{b}}$ \\
\hline
\end{tabular}

Superskrip berbeda pada kolom/baris yang sama menunjukkan perbedaaan secara signifikan $(\mathrm{P}<0,05)$ 
VLDL akan kehilangan trigliserida menjadi LDL karena lipoprotein lipase (LPL) yang diaktifkan oleh apoprotein. Partikel-partikel LDL yang kaya kolesterol dibawa ke jaringan tubuh menjadi membran, membentuk steroid atau mengendap dipembuluh darah. LDL akan ditangkap reseptor jaringan pada membran plasma selanjutnya protease lisosom mengkatalis hidrolisis LDL. Protein LDL didegradasi menjadi asam amino (Ngili, 2009). Berdasarkan jalur endogen, Mansoub (2011) berpendapat bahwa asam lemak Omega-3 dapat menurunkan kadar VLDL darah yang merupakan agen pembentuk LDL darah. Fungsi dari asam lemak tidak jenuh khususnya Omega3 yang dapat menurunkan biosintesis kolesterol dan sifatnya tidak menempel pada pembuluh darah, sehingga hal tersebut menguntungkan bagi kesehatan.

Pemberian minyak lemuru kurang mampu memberikan pengaruh nyata $(\mathrm{P}>0,05)$ pada kadar HDL darah, kecuali pada perlakuan T3 dengan nilai tertinggi. Penelitian Monfaredi et al. (2011) yang menggunakan minyak kedelai pada ransum ayam broiler mendapatkan hasil beda nyata $(\mathrm{P}<0,05)$ pada kadar HDL. Hal ini mungkin disebabkan karena imbangan asam-asam lemak yang belum sesuai khususnya asam lemak tidak jenuh yang terdapat pada ikan lemuru. Suripta \& Astuti (2007) menyatakan bahwa pemanfaatan Omega-3 dalam pakan tergantung pada keseimbangan asam lemak lainnya, terutama imbangan Omega-6 dan Omega-3 agar dapat diabsorbsi secara optimal, sehingga asam-asam lemak tersebut dapat dimanfaatkan tubuh.

Rataan kadar HDL dalam darah ayam kampung yang diberi ransum dengan perlakuan minyak ikan lemuru berkisar antara 40,36 $\mathrm{mg} / \mathrm{dl}$ sampai 49,64 mg/dl. Hazim et al. (2010) mendapatkan kadar HDL puyuh yang diberi minyak biji matahari sebesar $71,8 \mathrm{mg} / \mathrm{dl}$. Zuprizal et al. (2002) menyatakan kandungan HDL darah itik betina yang diberi perlakuan minyak ikan lemuru dan minyak kelapa sawit $64,35 \mathrm{mg} / \mathrm{dl}$. Pemberian ransum dengan minyak ikan lemuru $6 \%$ lebih tinggi kadar HDL darah bila dibandingkan dengan minyak ikan lemuru $4 \%$, 2\%, dan $0 \%$. Peningkatan tersebut berkaitan dengan semakin meningkatnya asam lemak tidak jenuh pada ransum yang mengandung minyak ikan lemuru terhadap kadar HDL. Hasil penelitian ini sejalan dengan penelitian Chashnidel et al. (2009) yang menunjukkan peningkatan kadar HDL dengan adanya peningkatan penambahan minyak ikan dan Rezaei et al. (2008) dengan penambahan minyak kedelai pada pakan.

Pembentukan HDL dimulai dari sintesis Apoprotein dan fospolipid di hati yang membentuk partikel HDL. Partikel-partikel ini sewaktu beredar dalam sirkulasi menyerap kolesterol dari jaringan dengan bantuan adenosine triphospate binding cassete transporter-1 (ABC-1) yang berfungsi mengeluarkan kolesterol dari makrofag. Lesitin kolesterol asil transferase (LCAT) mengesterifikasi kolesterol dalam HDL. Linder (2006) menyatakan bahwa peningkatan HDL dapat dipengaruhi oleh Lesitin kolesterol asil transferase (LCAT). Asam lemak tidak jenuh Omega-3 dapat menstimulan pada proses esterifikasi kolesterol. Selain itu asam linoleat merupakan asam lemak paling banyak ditranfer dari fosfatidilkolin atau lesitin pada kolesterol membentuk ester linoleoil kolesterol pada pembentukan HDL (Ngili, 2009). Fraksi ester kolesterol ini dapat berpindah jika kebutuhan meningkat ke VLDL selanjutnya berubah menjadi LDL untuk ikut serta dalam metabolisme membran dan steroid, selain itu diserap oleh hati untuk sintesis VLDL atau diekskresikan dalam empedu.

Absorpsi lemak merupakan masalah khusus, karena tidak seperti hasil akhir pencernaan, zat-zat ini tidak larut dalam air. Penyerapan zat ini dipermudah oleh kombinasi dengan garam empedu, karena kombinasi ini merupakan suatu susunan yang larut dalam air. Garam empedu dibebaskan dalam sel mukosa yang dapat dipergunakan lagi. Trigliserida dihidrolisis enzim lipase menjadi asam lemak, bersama kolesterol, dan fospolipid akan diemulsi oleh garam empedu menjadi misel. Widodo (2005) menyatakan misel akan diserap epitel usus yang akan cepat berubah menjadi trigliserida, fospolipid, dan kolesterol selanjutnya masuk kedalam peredaran darah dalam bentuk kilomikron dan dideposit pada jaringan atau dibawa ke hati.

High Density Lipoprotein(HDL) merupakan lipoprotein yang mempanyai kandungan protein paling tinggi daripada lipoprotein lainnya. Kandungan protein HDL berkisar antara 54 sampai 65\%. HDL mempunyai fungsi yang penting dalam mengikat kelebihan kolesterol beserta esternya dan mengangkutnya bersama aliran darah dari sel tepi ke sel hati. 
Pemberian minyak ikan lemuru berpengaruh nyata $(\mathrm{P}<0,05)$ pada kolesterol total kecuali R1. Kolesterol didalam tubuh diserap dalam bentuk asam kolat, di hati dikonjugasikan dengan bahan lain membentuk garam empedu yang membantu pencernaan dan penyerapan lemak. Kolesterol diedarkan ke seluruh sel oleh LDL dan HDL. Menurut George \& Michael (2010) Low density lipoprotein merupakan komponen lipoprotein yang memiliki peran terbesar membawa kolesterol ke jaringan tubuh yang digunakan dalam pembentukan membran atau menjadi hormon steroid. High density lipoprotein memiliki peran yang bertentangan dengan LDL, yaitu membawa kolesterol dan lipoprotein lainnya yang sudah terakumulasi dari sel dan membawa kolesterol kembali ke hati untuk selanjutnya diekskresikan dalam empedu (Gropper \& Smith, 2009).

Menurut Murray et al. (1999) kolesterol yang tidak diperlukan akan dikeluarkan bersama dengan ekskreta dalam bentuk garam empedu dan dalam bentuk hormon-hormon steroid netral. Jalur utama pembuangan kolesterol dari tubuh yakni melalui konversi oleh hati menjadi asam empedu, yaitu asam kholat dan chenodeoxy cholic yang berkaitan dengan glisin atau taurin membentuk garam empedu. Selanjutnya diekskresikan oleh empedu kedalam duodenum, sebagian besar asam empedu direabsorpsi oleh hati melalui sirkulasi yang selanjutnya disekresikan kembali dalam empedu. Asam empedu yang tidak diserap akan didegradasi oleh mikroba usus besar dan diekskresi melalui ekskreta (Daud et al., 2007).

\section{KESIMPULAN}

Kesimpulan penelitian adalah dengan pemberian minyak ikan lemuru sampai pada level 6\% mampu mempengaruhi profil lemak darah serta dapat digunakan dalam campuran pakan ayam kampung.

\section{DAFTAR PUSTAKA}

Adebisi F. A., R.O. Babatunde, \& O.O. Jeremiah. 2017. Influence of four dietary oils on selected blood constituents in egg-type chickens. Journal of Agricultural Sciences 62:251-263.

Amiluddin I., Dian A., \& R. Erna. 2014. Pengaruh penambahan ikan lemuru (Sardinella longiceps) terhadap karakteristik folikel dan siklus ovulasi pada ayam ras petelur. Jurnal Ilmu dan Teknologi Peternakan Tropis 1(1):45-53.

Chashnidel, H., H. Moravej, A. Towhidi, F. Asadi \& S. Zeinodini. 2010. Influence of different levels of n-3 supplemented (fish oil) diet on performance, carcass quality and fat status in broilers. African Journal of Biotechnology 9(5):687-691.

Daud, M., W.G. Piliang \& I.P. Kompiang. 2007. Persentase dan kualitas karkas ayam pedaging yang diberi probiotik dan prebiotik dalam ransum. JITV 12(3):167174.

George H.R. \& C.P. Michael. 2010. Highdensity lipoprotein heterogeneity and function in reverse cholesterol transport. Curr Opin Lipidol 21(3):229-238.

Gropper, S.S., \& J.L. Smith. 2009. Advanced Nutrition and Human Metabolism. 6th Edition. Wadsworth. Belmont.

Hartini, M. \& P.A. Okid. 2009. Kadar kolesterol darah tikus putih (Rattus norvegicus) hiperkolesterolemik setelah perlakaun VCO. Bioteknologi 6(2):5562.

Hazim J., Al-Daraji, Ali S., Al-Hassani, H.A. Al-Mashadani, W.K. Al-Hayani \& H.A. Mirza. 2010. Effect of dietary supplementation with sources of omega-3 and omega- 6 fatty acids on certain blood characteristics of laying quail. J. Poult. Sci. 9(7):689-694.

Linder, M.C. 2006. Biokimia Nutrisi dan Metabolisme dengan Pemakaian secara Klinis. UI Press. Jakarta.

Mansoub, N. H. 2011. Effect of fish oil fed a low-protein diet on performance, carcass characterizes and blood indices in broiler chicks. Journal of Biological Research 2(3):113-120.

Marks, D.B., D. Allan, \& M. Collen. 2000. Biokimia Kedokteran Dasar. Alih bahasa Brahm U. EGC. Jakarta.

Mariod A. A, A.E.M. Manahil, E.S. Mohamed, \& H. Tjahjono. 2015. Effect of addition of fish oil on the performance parameters of laying hens and the fatty acid composition of their egg yolk. American 
Journal of Food Science and Health 1:3842.

Monfaredi, A., M. Rezaei, \& H. Sayyahzadeh. 2011. Effect of supplemental fat in low energy diets on some blood parameters and carcass characteristics of broiler chicks. South African Journal of Animal Science 41(1):24-32.

Murray, R.K., D.K. Granner, P.A. Mayes, \& V.W. Rodwell. 1996. Biokimia Harper. EGC. Jakarta

Ngili, Y. 2009. Biokimia Metabolisme dan Bioenergitika. Graha Ilmu. Yogyakarta.

Nurul, F. 2016. Blood cholesterol, LDL and hdl in crossbred local chicken feed inulin of dahlia tubers as a prebiotic. Chalaza Journal of Animal Husbandry 1:1-5.

Sacher. R. A., A. Richard, \& McPherson. 2004. Tinjauan Klinis Hasil Pemeriksaan Laboratorium Edisi 11. EGC. Jakarta.
Suripta, H. \& P. Astuti. 2007. Pengaruh Penggunaan Minyak Lemuru dan Minyak sawit dalam ransum terhadap rasio asam lemak omega-3 dan omega-6 dalam telur burung puyuh (Coturnix coturnix japonica). Journal Indonesia Tropical Agricultur 32(1):22-27.

Widodo, W. 2005. Nutrisi dan Pakan Unggas Kontekstual. UMM. Malang.

Zuprizal, T.N. Cuk, Indratiningsih, \& H. Sri. 2002. Studi Transfer Omega-3 yang Berasal dari Limbah Industri Pengolahan Ikan terhadap Komposisi Kimia Telur Berbagai Jenis Unggas. Lemlit-UGM. Yogyakarta. 